\title{
The Role of Principal Leadership in Managing School-Based Management Supardi $^{1 *}$, Happy Fitria ${ }^{2}$, Alfroki Marta ${ }^{2}$
}

\author{
${ }^{1}$ SDN 6 Sumber Marga Telang \\ ${ }^{2}$ Universitas PGRI Palembang \\ * Corresponding author. Email: entrimujyonosmp1@gmail.com
}

\begin{abstract}
The research was conducted by using a qualitative method. The data sources of this research are the principal and teachers. Data collection techniques are observation, interview, and documentation. The location of the research is at SDN 3 Sumber Marga Telang, Banyuasin Regency. The results of this study indicate that: (1)The leadership of the principal has played a role in managing school-based management at SDN 3 Sumber Marga Telang, Banyuasin Regency, where the management of the curriculum is designed according to the 2018 Ministry of Education and Culture's instructions which refers to the 2013 curriculum using a character approach; (2) The obstacles faced by the principal as the leader in SDN 3 Sumber Marga Telang, Banyuasin Regency in managing school-based management are as follows. (1) The management of the curriculum that has been designed has not been running optimally, which is currently still in the state of the Covid-19 pandemic, so that the distribution of the learning process is still carried out by an online system; (2) The management of facilities and infrastructure cannot be completely completed, due to the limited funds available, both funds from the school itself and assistance from the Banyuasin Regency government. Because other schools also need funds for school progress; (3) Current data collection on student management is constrained by electricity, where in the Sumber Marga Telang area, Banyuasin Regency often goes out.
\end{abstract}

Keywords: Principal, Leadership, School Based Management

\section{INTRODUCTION}

Education is a very important and strategic aspect in the development and enhancement of development in all fields including in the regions, so that decentralization of education in the context of regional autonomy cannot be negotiated in the context of improving the quality of education and human resources. One model of decentralized education is School Based Management (SBM), which aims to improve the quality of education in Indonesia [1]. School-based management (SBM) is a model of bureaucratic reform as a consequence of decentralization in the world of education to create a better future school form compared to the previous one. MBS emphasized that the concept refers to resource management at the school level and not at a centralized system or level [2]. It is understood as an alternative formal choice for managing decentralized education by placing schools as the main unit for improving the quality of education [3].

One of the most important features of the implementation of SBM is how the school is able to provide satisfactory educational services to parents of students and the community, and vice versa to the extent of the readiness and role of the community and parents of students in contributing to developing and improving the quality of schools in accordance with community needs. The implementation of SBM in schools requires the readiness of various components and educational instruments both internally and externally that can support the implementation of SBM itself, including: school buildings equipped with learning facilities and infrastructure, school principals, educators and education personnel, students, environment school participation of students' parents, community support and other businesses. SBM is one of the government's efforts to achieve community excellence in the mastery of science and technology and identity as a religious and cultured nation. School-based management aims so that school autonomy and community participation or local stakeholders have high involvement, and provide a basic framework that each element will be able to play a role in improving the quality, efficiency and equitable distribution of educational opportunities [4].

The main problem of the quality of education at this time is that it relies more on the quality of graduates produced by the education unit itself. In this connection, explains that, in general, quality implies the level of excellence of a product in the form of goods / services, both real and unreal. Whereas in the context of 
education, the definition of quality refers to the educational process that includes inputs, such as teaching materials, methodologies, school facilities, administrative support for infrastructure, other resources and the creation of a conducive atmosphere. Therefore, the quality of education implies the ability of school resources to transform various types of input and situations to achieve certain degrees of added value for students.

In connection with the description above, SBM is very important to be implemented in the school environment, because with good school-based management its implementation will be able to contribute to improving the quality of education. The quality of education will not run well without the implementation of good school-based management. Based on preliminary data obtained that at SDN 3 Sumber Marga Telang, Banyuasin Regency, the implementation of school-based management in terms of curriculum management has been carried out in accordance with the applicable curriculum, but it still needs to be improved so that it is even better in the future. The management of infrastructure and facilities still needs to be improved, because there are still several facilities that are no longer suitable for use, such as examples of teaching aids are still lacking, student toilets, student handbooks, teacher's book as a guide for teaching. Teacher quality management, currently at SDN 3 Sumber Marga Telang has a total of 20 teachers consisting of 6 PNS teachers and 14 honorary teachers. As many as 6 educational staff. Of the 6 PNS teachers who already have teaching certificates, 3 are PNS teachers and 3 PNS teachers do not have Educator certificates.

Administrative management in the process of activities at SDN 3 Sumber Marga Telang has been carrying out tasks as arranged and assigned by the school principal, such as making correspondence, filing school data, taking inventory of school items, making a list of student names. However, what has not been considered optimal in administrative management is filing without numbering, so it is difficult to retrieve the documents that have been archived, and existing inventory items have not been labelled with an accurate numbering in accordance with the list of inventory items.

\section{METHODS}

This type of research is qualitative research, research Qualitative is research to describe and analyze phenomena, events, social activities, beliefs, perceptions, thoughts individually or in groups. The focus of this research is school-based management (SBM) is very important to be implemented in the school environment
The informants who were interviewed in this study were as follows: teachers of SDN 3 Sumber Marga Telang, Banyuasin Regency. Collecting data in this study using interviews, observation and documentation. Then analyzed by triangulation rules, source triangulation to test the credibility of the data is done by checking the data that has been obtained through several sources or informants. This is done until the data trend is obtained so that the data can be viewed as containing truth values

\section{RESULTS AND DISCUSSION}

Based on the results, the leadership of the principal has played a role in managing school-based management at SDN 3 Sumber Marga Telang, Banyuasin Regency, where the management of the curriculum is designed according to the 2018 Ministry of Education and Culture's instructions which refers to the 2013 curriculum using a character approach. The leadership of the principal has played a role in managing school-based management at SDN 3 Sumber Marga Telang, Banyuasin Regency, where the management of facilities and infrastructure has been made the best possible effort to complement the existing lack of facilities. This is evidenced by obtaining grants from the Banyuasin Regency government through ABPD funds and from the Special Allocation Fund (DAK). The leadership of the principal has played a role in managing school-based management at SDN 3 Sumber Marga Telang, Banyuasin Regency, where student management has recorded and distributed the implementation of tasks that are carried out to manage everything related to students. The leadership of the principal has played a role in managing school-based management at SDN 3 Sumber Marga Telang, Banyuasin Regency, where teacher quality management has been made to improve teacher professionalism by sending teachers to attend training, KKG, seminars and other activities that add insight to teachers in teaching and striving for teachers to obtain educator certificates.

The results are similar to Bush who stated that the role of the principal as an educator is to shape a culture of teaching and learning that is conducive to learning [5]. The school principal carries out mental coaching by fostering educational staff on matters related to mental attitudes and character [6]. In this case the school principal creates a conducive climate so that every educational staff is able to carry out their duties properly, proportionally and professionally. For this reason, the principal should try to complete the facilities, infrastructure and learning resources in order to make it easier for teachers and students in their main tasks, namely learning / teaching. 
The obstacles faced by the principal as the leader at SDN 3 Sumber Marga Telang, Banyuasin Regency in managing school-based management are as follows. (1) The management of the curriculum that has been designed has not run optimally, which is currently still in the state of the Covid-19 pandemic, so that the distribution of the learning process is still carried out by an online system; (2) The management of facilities and infrastructure cannot be fully completed, due to the limited funds available, both from the schools themselves and assistance from the Banyuasin Regency government. Because other schools also need funds for school progress; (3) Current student management data collection is constrained by electricity, where in the Sumber Marga Telang area, Banyuasin Regency often goes out. Furthermore, the existing network is not optimal, so that internet data usage cannot be used optimally (low signal); (4) The role of the principal's leadership in managing school-based management at SDN 3 Sumber Marga Telang, Banyuasin Regency, in terms of the quality of the current teachers, has not yet been fully realized, where teachers who obtain teacher certificates are only $50 \%$ of the total number of teachers currently available. In other words, the leadership of the principal in managing school-based management in terms of teacher quality must be improved again, so that in the future it can be realized that overall teachers already have educator certificates. In terms of teacher quality, it is currently not fully realized, where teachers who have received teacher certificates are only $50 \%$ of the total number of teachers currently available. In other words, the leadership of the principal in managing school-based management in terms of teacher quality must be improved again, so that in the future it can be realized that overall teachers already have teacher certificates. In terms of teacher quality, it is currently not fully realized, where teachers who have received teacher certificates are only $50 \%$ of the total number of PNS teachers currently available. In other words, the leadership of the principal in managing school-based management in terms of teacher quality must be improved again, so that in the future it can be realized that overall teachers already have educator certificates. Despite the quality improvement efforts education is built from various aspects, but obstacles remain. Lack of communication and leading discussion are clear problems of school based management [7].

Based on the theories used as a reference in this study, it provides an overview of the role of principal leadership in managing school-based management, that a leader in a school is finally called the Principal, in the context of the principal's duties are very heavy because it must be able to play a double role. Apart from being a leader, of course, they are able to become partners of teachers in teaching and educating their students. And of course every leader has his own way and method of carrying out his duties and functions. According to Wuradji [8], the principal role comprises of (1) planning carefully about goals and strategies for achieving goals, (2) organizing potential educational resources available, (3) carrying out activities, and (4) carry out regular control over the implementation and outcomes of education.

Confirmed regarding the leadership role of the principal, and the expectations that a school wants to achieve, teacher professionalism is the key that must be worked on. Teacher professionalism is the work of teachers that are reflected in designing teaching programs or planning teaching, teaching implementation, interpersonal relationships, and evaluating learning outcomes.

Principals who succeed when they understand the existence of the school as a complex and unique organization, and are able to carry out the role of the principal as a supervisor who is given the responsibility to lead the school. The achievement of educational goals is highly dependent on the leadership skills and policies of the principal as a supervisor who is one of the education leaders. Because the principal is a professional official in the school organization in charge of managing all organizational resources and collaborating with teachers in educating students to achieve educational goals. With the professionalism of the principal as a supervisor for the professional development of educational personnel, it is easy to do because in accordance with his function, the principal understands the needs of the school he leads so that the competence of teachers is not only the competencies he had before, but increases and develops well so that the performance of teacher professionalism will be realized. The role of the principal as the leader of the school has the responsibility of mobilizing all existing resources in the existing school so that it creates a work ethic and high productivity in achieving goals [9].

According to Mulyasa [10] there are several factors that make a leader increase the professionalism of his subordinates. First, the leader meets the needs of his subordinates with regard to the effectiveness of the job. Second, leaders provide the training, guidance and support their employees need. In an effort to increase the professionalism of subordinates, the role of leadership is very important, because the success or failure of an achieved goal depends on the leadership. And this is an obligation for each leader to be able to lead his subordinates to work in accordance with the instructions given so that it will create conditions and a work environment that encourages activities to achieve organizational goals effectively and efficiently. 


\section{CONCLUSION}

Based on the result and discussion, it can be concluded that the principal of SDN 3 Sumber Marga Telang, Banyuasin Regency has performed the leadership in the school based management as it is required. The principal guides the school in the case of curriculum following the national determination. Besides, the principal also pays attention on the infrastructures needed in the school. It is hoped that the school based management can be applied in order to maintain the improvement of schools.

\section{REFERENCES}

[1] Anwar, M. (2013). Educational Administration and Education Cost Management. Jakarta: Raja Grafindo Persada.

[2] Nawawi, H. (2016). School Administration. Jakarta: Ghalia Indonesia.

[3] Abu, Ibtisan and Duhou. (2002). SchoolBased Management. Paris: United Nations Educational, Scientific and Cultural Organization.

[4] Fattah, N. (2004). Konsep Manajemen Berbasis Sekolah (MBS) dan Dewan Sekolah. Bandung: Pustaka Bani Quraisy.

[5] Bush, Tony \& Coleman Marieanne. (2006). Culture foundation of education; an interdisciplinary exploration. New York: Haper and Brethers Publishers.

[6] Mulyasa, E. (2007). Menjadi kepala sekolah profesional. Bandung: PT Remaja Rosdakarya.

[7] Haryanto, I. and Mlati, P. (2014). Peran Kepala Sekolah dalam Penerapan Manajemen Berbasis Sekolah (MBS) di SDIT Jabal Nur Gamping, Sleman. Jurnal Akuntabilitas Manajemen Pendidikan. 2(2). 174-187.

[8] Wuradji. (2009). The educational leadership, kepemimpinan transformasional. Yogyakarta: Gama Media.

[9] Wahjosumidjo. (2001). Kepemimpinan kepala sekolah. Jakarta: PT Raja Grafindo Persada.

[10] Mulyasa, (2013). Principal Management and Leadership. Jakarta: Bumi Aksara. 